\title{
A note about source material
}

The search for authenticity concerning Shaka Zulu poses a challenge, because it is based on (1) the imagery of Shaka available within African society, a blending of oral and written tradition, and (2) perceptions of traders and colonial officials. Over time Shaka's image has become mythopoetic, its details contested between white and black historians. Many writers have demonized him, creating a figure of inhuman qualities, a symbol of violence and terror. European writers with this perspective have been accused of reinventing Shaka as a monster as justification for stealing African land. (It should be noted, however, that many of the most horrendous stories drew on tales already in existence before the arrival of whites.)

Shaka's early life is remembered through oral tradition, which was the way traditional Zulu society kept records. Separating first-hand accounts from hearsay leads to problems of intepretation. In contrast, many facts of his later life are based on the written accounts of the first white adventurers, who established a settlement at Port Natal - modern-day Durban - in 1824. Predominantly British, they thrived under Shaka's protection, hunting for ivory and trading with the Zulu kingdom.

The main source of written information, not only for me but for researchers generally, is the detailed eyewitness accounts of Nathaniel Isaacs (1836) and Henry Francis Fynn (1833/1950), both of whom had personal contact with Shaka. These two traders wrote accounts of their interactions with the African king that smack of sensationalism, probably in order to capture the attention of their audience.

Analysis of the texts of Isaacs and Fynn reveals that both accounts are highly problematic, containing internal contradictions. Nathaniel Isaacs's portrait of Shaka was, in his own words, 'somewhat incredible, if not highly exaggerated'. When Isaacs heard that Fynn was writing a book on Shaka, he advised him to depict the African leader as being as bloodthirsty as possible (though neither writer had had significant problems dealing with him), to get the attention of the readers. Fortunately, Fynn does not seem to have taken Isaacs's advice to heart. Thus his diary, from the point of view of perspective, is a more reliable source. However, the diary had to be reconstructed later from fragmentary notes, because the original was lost. (According to one romantic version it was buried by mistake - wrapped in an elephant's ear - in the grave of the writer's brother.) 
Other information comes from colonial administrators. One colonial official in particular - James Stuart - engaged in systematic research of the reign of Shaka. Between 1897 and 1924 he collected the stories of nearly 200 informants concerning the history of the Zulu and neighboring people. His collection of oral history is the main source for historical research of that period, and I have relied on it heavily.

In addition, the first book ever written in Zulu by a Zulu author, Magema Fuze, contains a rich store of oral knowledge that the author gathered through his wide network of contacts. This book, Abantu Abamnyama (The Black People), was privately published in 1921, when the author was approximately 82 years old.

One very popular book on Shaka by Edward Ritter needs to be called into question. Notwithstanding its listing of many original sources, it plagiarizes extensively (particularly from Alfred Bryant's book Olden Times in Zululand and Natal), embellishing and fantasizing the original texts. Other works verge into historical invention because their authors were determined to fit the facts to a specific worldview.

Three kinds of Shaka sources are used in these pages:

1. Narratives of peopIe who knew (or at least met) Shaka personally.

2. Accounts from people who knew people who knew Shaka (including contributions from Europeans and researchers who collected oral history).

3. Zulu praise songs, known as izibongo - portrayals of Shaka that have evolved over the years

All these accounts need to be treated with care, given problems of translation of accounts from the Zulu language, and problems of interpretation resulting from the subjectivity and the biases of the authors. Because the early traders and colonists gave a Eurocentric interpretation of the behavior of the Zulus, perceptual confusion was compounded.

Because of the emotional symbolism attached to the person of Shaka, it is particularly difficult to separate fact from fiction in accounts of his life. Indicators for the existence of a twilight zone surrounding the man include the many versions circulating about his birth and early life, the nature of his personal relationships, and his much-recounted cruelty. Given the great confusion concerning certain episodes and events in his life, I have tried to be parsimonious and have aimed at triangulation. I have focused on episodes in Shaka's life where many different authors have reached some form of consensual agreement, and on themes implied in the mythopoeic presentation of Shaka. 


\author{
To Alicia, \\ Eva, \\ Fredrik \\ and Oriane \\ who helped me \\ retain my sense of \\ imagination, curiosity \\ and wonder.
}

